\title{
EVALUASI UJI IRITASI DAN UJI SIFAT FISIK SEDIAAN EMULGEL MINYAK ATSIRI BUNGA CENGKEH (Syzigium aromaticum)
}

\section{IRRITATION TEST AND PHYSICAL PROPERTIES EVALUATION OF ESSENTIAL OILS CLOVE (Syzigium aromaticum) IN EMULGEL}

\author{
Delia Komala Sari ${ }^{1}$, Nining Sugihartini ${ }^{1,2}$, Tedjo Yuwono ${ }^{1,2}$ \\ ${ }^{1}$ Program Pasca Sarjana Farmasi, Universitas Ahmad Dahlan, Yogyakarta \\ ${ }^{2}$ Fakultas Farmasi Universitas Ahmad Dahlan, Yogyakarta Telp. (0274) 379418 \\ Email: deliafarmasi@gmail.com
}

Reviewed : 31-08-2015

Accepted: 24-11-2015

\begin{abstract}
ABSTRAK
Inflamasi merupakan respon tubuh terhadap terjadinya kerusakan jaringan yang ditunjukkan dengan adanya peningkatan permeabilitas vaskuler. Salah satu bahan alam yang dapat digunakan untuk mengatasi inflamasi adalah minyak atsiri bunga cengkeh (MABC). Penelitian ini bertujuan untuk mengevaluasi sifat fisik dan uji iritasi sediaan emulgel MABC (Syzygium aromaticum). Penelitian eksperimental ini diawali dengan melakukan formulasi emulgel dengan 3 macam formula, masing-masing dengan kadar MABC 10\% (F1), 12,5\% (F2), dan 15\% (F3). Parameter uji fisik yang dilakukan adalah $\mathrm{pH}$, daya sebar dan daya lekat emulgel serta uji iritasi sediaan pada hewan uji marmut dengan metode Draize test. Analisis statistik dengan uji t dengan taraf kepercayaan $95 \%$ untuk mengetahui adanya perbedaan yang signifikan antar kelompok perlakuan. Formula emulgel dengan konsentrasi 10\%, 12,5\% dan 15\% stabil secara tampilan fisiknya, selanjutnya uji daya sebar untuk masing-masing formula diperoleh data distribusi normal $(p>0,05)$ dan homogen $(p>0,05)$. Hasil uji ANOVA diperoleh hasil yang berbeda signifikan pada masing-masing formula $(\mathrm{p}<0,05)$, sedangkan hasil uji daya lekat masing-masing formula lebih dari 30 menit dengan $\mathrm{pH}$ 6. Hasil uji iritasi dengan metode Draize test, ternyata masing-masing formula tidak memperlihatan efek iritasi.
\end{abstract}

Kata kunci: eugenol, emulgel, antiinflamasi, Syzigium aromaticum

\begin{abstract}
Inflammation is the human body's response to a tissue damage as indicated by an increase of vascular permeability. One of the natural substances that can be used to treat inflammation is clove oil (MABC). This study aimed to evaluate the physical properties and MABC emulgel irritation test (Syzygium aromaticum). This experimental study was initiated by the emulgel formulation with three kinds of formula, with each formula contains MABC levels of $10 \%(\mathrm{~F} 1), 12.5 \%(\mathrm{~F} 2)$, and $15 \%(\mathrm{~F} 3)$. The physical tests for emulgel was done including $\mathrm{pH}$, spreading test and adhesive test and irritation test in guinea pigs using Draize test method. Statistical analysis by t test with a level of confidence 95\% was conducted to detect a significant differences between the treatment groups. The emulgel formula with a concentration of $10 \%, 12.5 \%$ and $15 \%$ were physically stable, moreover the dispersive power test for each formula showed normal distribution data $(p>0.05)$ and homogeneous $(p>0.05)$, ANOVA test results obtained significantly different results in each formula $(p<0.05)$, whereas the stickiness test results for each formula more than 30 minutes with $\mathrm{pH}$ 6. The results of irritation test by using Draize test method, indicated that each formula did not show any irritant effect.
\end{abstract}

Keywords: eugenol, emulgel, antiinflammatory, Syzigium aromaticum 


\section{PENDAHULUAN}

Minyak cengkeh merupakan minyak atsiri yang berasal dari tanaman cengkeh (Syzigium aromaticum), yang termasuk dalam famili Myrtaceae (Alma, et al, 2007). Penelitian yang dilakukan oleh Nurdjanah pada 2004 menyebutkan bahwa eugenol (Gambar 1) merupakan komponen terbesar yang terdapat dalam minyak atsiri cengkeh yaitu sebesar $70-80 \%$ (Nurdjanah,N, 2004).

Eugenol (4-allyl-2-methoxyphenol) merupakan kandungan dari minyak atsiri yang biasa digunakan sebagai pengaroma pada produk makanan dan kosmetik. Studi terdahulu mengungkapkan bahwa eugenol dan komponen fenolik lain memiliki aktivitas sebagai antioksidan dan antiinflamasi yang bekerja menghambat sintesis prostaglandin dan neutrohil chemotaxis (Ma dan Kinneer, 2002).

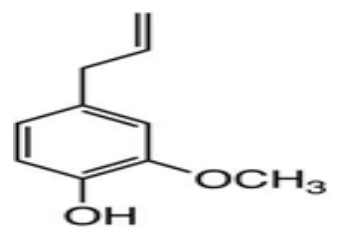

Gambar 1. Struktur kimia eugenol (Kamatou dkk., 2012)

Berdasarkan potensi eugenol sebagai antiinflamasi, dibuatlah bentuk sediaan berupa emulgel. Aplikasi langsung pada tempat inflamasi diharapakan dapat mempercepat proses penyembuhan, sehingga peneliti ingin membuat sediaan topikal dari minyak cengkeh.

Emulgel merupakan pengembangan dari sediaan gel. Emulgel terdiri dari dua fase, yaitu fase besar molekul organik yang terpenetrasi dalam air dalam bentuk gel dan fase kecil minyak emulsi. Adanya fase minyak di dalamnya menyebabkan emulgel lebih unggul dibandingkan dengan sediaan gel sendiri, yakni obat akan melekat cukup lama di kulit dan memiliki daya sebar yang baik, mudah dioleskan serta memberikan rasa nyaman pada kulit (Magdy, 2004).

\section{METODE PENELITIAN}

\section{Alat dan Bahan}

Alat - alat yang digunakan dalam penelitian ini antara lain alat uji daya lekat, alat uji daya sebar, dan $\mathrm{pH}$ meter.

Bahan-bahan yang diperlukan adalah minyak atsiri bunga cengkeh (MABC) yang diperoleh dari Center of Essential Oil Studies (CEOS) Universitas Islam Indonesia, Yogyakarta. Bahan yang digunakan untuk formulasi sediaan emulgel adalah $\mathrm{Na} \mathrm{CMC}$, parafin cair, sorbitol, span 80, tween 80, metil paraben, propil paraben, dan Aquadest. Hewan uji marmut jantan.

\section{Jalannya Penelitian}

Formulasi emulgel disajikan pada Tabel I. Pada masing masing formula tersebut divariasi konsentrasi MABC $10 \%, 12,5 \%$ dan $15 \%$.

Tabel I. Formulasi sediaan gel minyak atsiri bunga cengkeh (\%)

\begin{tabular}{cccc}
\hline Bahan & F1 & F2 & F3 \\
\hline MABC & 10 & 12,5 & 15 \\
Na CMC & 1,5 & 1,5 & 1,5 \\
Sorbitol & 1 & 1 & 1 \\
Parafin cair & 1,25 & 1,25 & 1,25 \\
Span 80 & 2,5 & 2,5 & 2,5 \\
Tween 80 & 17,5 & 17,5 & 17,5 \\
Metil paraben & 0,18 & 0,18 & 0,18 \\
Propil paraben & 0,02 & 0,02 & 0,02 \\
\hline
\end{tabular}


Formulasi sediaan emulgel dilakukan dengan terlebih dahulu membuat fase gel dengan mencampurkan Na CMC dengan aquadest. Kemudian didiamkan selama 2 kali 24 jam agar fase gelnya mengembang. Dilanjutkan dengan membuat fase emulsi dengan teknik peleburan. Setelah fase emulsi dingin kemudian ditambahkan mabc dengan variasi konsentrasi. Kemudian fase emulsi ditambahkan dalam fase gel dan diaduk hingga homogen.

\section{Evaluasi sifat fisik emulgel}

1. Penetapan $\mathrm{pH}$

Sejumlah $0,5 \mathrm{~g}$ emulgel diencerkan dengan $5 \mathrm{ml}$ aquades, kemudian di cek pHnya (Naibaho et al., 2013)

2. Uji daya sebar

Sejumlah 0,5 g emulgel diletakkan diatas kaca bulat, kaca lainnya diletakkan diatasnya dan dibiarkan selama5 menit. Diameter sebar salep diukur. Kemudian, ditambahkan $50 \mathrm{~g}$ beban tambahan dan didiamkan selama 1 menit lalu diukur diameternya. Kemudian ditambahkan $100 \mathrm{~g}$ beban dan ditunggu 1 menit lalu diukur diameter yang konstan (Naibaho et al., 2013)

3. Uji Daya Lekat

Sebanyak 0,25 g emulgel diletakkan di atas objek gelas yang telah ditentukan luasnya. Kemudian ojek gelas lainnya diletakkan di atas.Objek gelas kemudian dipasang pada alat uji dan diberi beban $1 \mathrm{~kg}$ selama 5 menit. Kemudian dilepas dengan beban seberat 80 gram. Dicatat waktunya hingga kedua gelas obyek tersebut terlepas (Naibaho et al., 2013)

\section{Evaluasi daya iritasi emulgel}

Evaluasi daya iritasi sediaan emulgel dilakukan terhadap hewan uji marmut dengan menggunakan metode Draize (1959). Dengan menggunakan 6 ekor marmut berumur rata-rata 2 bulan. Rambut marmut dicukur pada bagian punggungnya sampai bersih. Untuk membantu menghilangkan bulu halus digunakan veet. Punggung marmut dibagi menjadi 6 bagian dengan luas yang sama kemudian diberikan perlakuan sediaan emulgel F1, F2, F3, basis, kontrol sakit dan kontrol sehat. Masing-masing sampel iritan sebanyak 0,5 gram dioleskan pada bagian punggung marmut yang telah dicukur, lalu ditutup dengan kasa steril kemudian direkat-kan dengan plester. Setelah 24 jam, plester dibuka dan dibiarkan selama 1 jam, lalu diamati. Setelah diamati, bagian tersebut ditutup kembali dengan plester yang sama dan dilakukan pengamatan kembali setelah 72 jam. (Irsan et al, 2013). Untuk setiap keadaan kulit diberi nilai seperti pada Tabel II. (Draize, 1959).

\section{HASIL DAN PEMBAHASAN}

Penelitian ini dilakukan dengan membuat konsentrasi MABC 10\%, 12,5\%, dan 15\%. Dari 3 variasi konsentrasi ini diperoleh formula yang baik secara tampilan fisiknya dengan sediaan emulgel berwarna putih kekuningan.

Pada sediaan emulgel, beberapa evaluasi dilakukan untuk melihat kualitas fisik dari sediaan antara lain uji daya sebar, daya lekat dan $\mathrm{pH}$. Uji daya sebar pada salep dilakukan untuk melihat kemampuan sediaan menyebar pada kulit, dimana suatu sediaan emulgel sebaiknya memiliki daya sebar yang baik untuk menjamin pemberian bahan obat yang memuaskan (Naibaho et al., 2013). Penelitian terdahulu menyebutkan daya sebar yang baik untuk sediaan topikal adalah sekitar $5-7$ cm (Ulaen, et al., 2012).

Hasil pengujian daya sebar pada penelitian ini didapatkan di atas dari syarat yang ditentukan (Gambar 2). Dapat dilihat bahwa diameter penyebaran formula 3 lebih besar jika dibandingkan dengan formula 1 dan formula 2. Hasil kemudian diuji statistika dengan uji anova $(p<0,05)$ dan didapatkan hasil F1, F2, dan F3 memiliki perbedaan yang signifikan.

Hal ini berarti dengan peningkatan konsentrasi minyak atsiri dapat meningkatkan luas penyebaran sediaan.

Pengujian daya lekat dimaksudkan untuk melihat berapa lama kemampuan emulgel untuk melekat. Hasil pengujian daya lekat menunjukkan bahwa daya lekat dari emulgel lebih dari 30 menit. Syarat untuk daya lekat pada sediaan topikal pada penelitian sebelumnya disebutkan 
adalah tidak kurang dari 4 detik (Ulaen, et al., 2012), hal ini menunjukkan sediaan emulgel dengan berbagai konsentrasi minyak atsiri memenuhi persyaratan daya lekat dengan kemampuan melekat yang tinggi. Keuntungan dengan semakin tingginya daya lekat sediaan topikal emulgel ini adalah diharapkan semakin banyak zat aktif yang dapat terabsorpsi karena lamanya sediaan kontak dengan kulit.

Uji pH sediaan dilakukan menggunakan kertas pH dan diperoleh hasil (Gambar 3.) bahwa masing-masing sediaan berada pada $\mathrm{pH} 6$ yang artinya ada pada $\mathrm{pH}$ kulit dan diharapkan tidak mengiritasi pada penggunaannya.

Pengamatan terhadap iritasi pada hewan uji dilakukan dengan mengoleskan sediaan emulgel F1, F2, dan F3, basis emulgel, kontrol sakit menggunakan croton oil dan kontrol sehat yaitu bagian kulit yang tidak diberikan perlakuan. Pengamatan dilakukan dengan menggunakan metode Draize dan diamati terhadap eritema dan udema yang terjadi pada kulit marmut. Kemudian di hitung skoring eritema dan udema yang terjadi, serta dihitung indeks iritasi yang terjadi.

Hasil indeks iritasi dari kontrol sehat, kontrol basis, dan sediaan emulgel MABC pada F1, F2, dan F3 adalah tidak mengiritasi, sedangkan pada kontrol sakit terjadi iritasi ringan (Gambar 4.).

Tabel I. Formulasi sediaan gel minyak atsiri bunga cengkeh (\%)

\begin{tabular}{cccccc}
\hline nilai & $\begin{array}{c}\text { Eritema } \\
\text { karakteristik }\end{array}$ & nilai & $\begin{array}{c}\text { Edema } \\
\text { karakteristik }\end{array}$ & nilai & $\begin{array}{c}\text { Iritasi } \\
\text { karakteristik }\end{array}$ \\
\hline 0 & tidak ada & 0 & tidak ada & 0 & tidak ada \\
1 & sangat ringan & 1 & sangat ringan & 1 & sangat ringan \\
\hline 2 & ringan & 2 & Ringan & 2 & ringan \\
3 & sedang & 3 & Sedang & 3 & sedang \\
4 & berat & 4 & Berat & 4 & berat \\
\hline
\end{tabular}

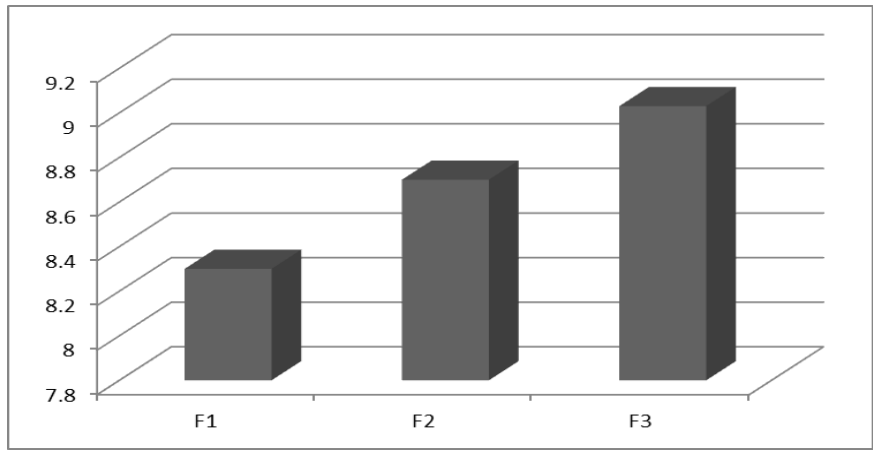

Gambar 2. Hasil uji daya sebar

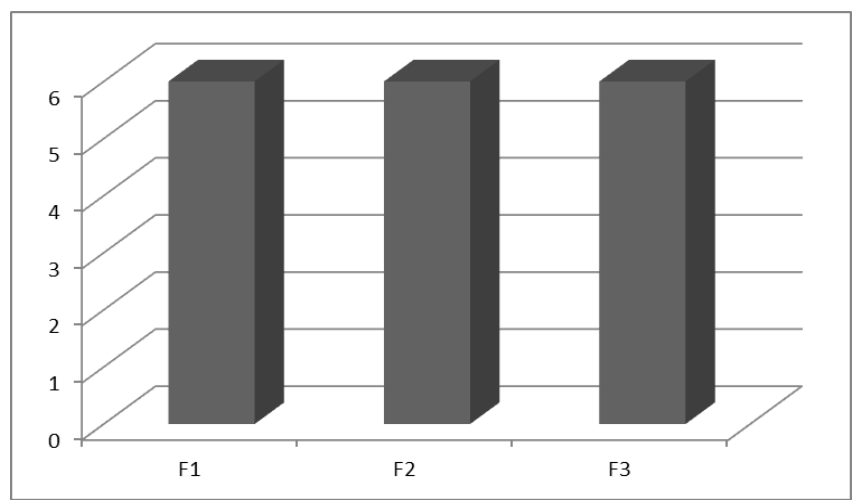

Gambar 3. pH sediaan emulgel 


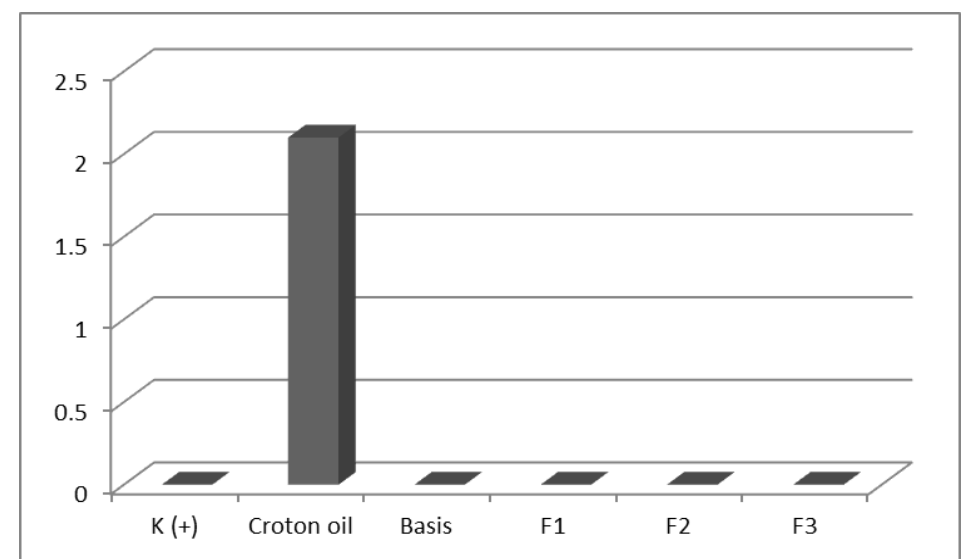

Gambar 4. Hasil perhitungan indeks iritasi

\section{KESIMPULAN}

Hasil uji sifat fisik sediaan emulgel F1, F2 dan F3 memberikan hasil yang baik dan memenuhi persyaratan sifat fisik sediaan. Hasil percobaan uji iritasi menunjukkan sediaan emulgel tidak menimbulkan iritasi pada hewan uji marmut jantan.

\section{UCAPAN TERIMAKASIH}

Penelitian ini terselenggara atas bantuan Hibah DIKTI melalui skema penelitian Tim Pasca Sarjana Tahun Anggaran 2015.

\section{DAFTAR PUSTAKA}

Alma,M.H., Ertas, M., Nitz, and Kollmannsberger, H., 2007, Chemical Composition and Content of Essential Oil from Bud of Cultivated Turkiish Clove (Syzygium aromaticum L.), BibResouces, 2(2), $265-269$

Draize, J.H. 1959. Dermal Toxicity. The Association of Food and Drug Officials of the United States, Bureau of Food and Drugs, Austin, TX. pp. 46-49. Available as PDF file

Irsan dkk, 2013, Uji Iritasi Krim Antioksidan Ekstrak Biji Lengkeng (Euphoria longana Stend) pada Kulit Kelinci (Oryctolagus cuniculus), Majalah Farmasi dan Farmakologi, Vol. 17, No.2 - Juli 2013, hlm. $55-60$

Kamatou, G.K., Vermaak, I., and Viljoen, A.M., 2012, Eugenol-From the Remote Maluku Islands to the International Market Place: A Review of a Remarkable and Versatile Molecule, Molecules, 17:6953-6981

Ma Q and Kineer K., 2002, Chemoprotection by phenolic antioxidants, inhibition of tumor necrosis factor alpha induction in macrophages, J Biol Chem., 277:2477-2484

Magdy IM. 2004. Optimization of Chlorphenesin Emulgel Formulation. The AAPS journal.october.6(3)(8 halaman). Diambil dari : http//www.aapspharmsci.org/

Naibaho, D.H., Yamkan, V,Y., Weni, Wiyono., 2013. Pengaruh Basis Salep Terhadap Formulasi Sediaan Salep Ekstrak Daun Kemangi (Ocinum sanchum L.) pada Kulit Punggung Kelinci yang dibuat Infeksi Staphylococcus aureus, Jurnal ilmiah Farmasi UNSRAT, Vol.2 N0.02

Nurdjannah,N.,2004. Diversifikasi Tanaman Cengkeh, J.Perspektif, Desember, hal : 3, 2, 61-70 Ulaen, Selfie P.J., Banne, Yos Suatan \& Ririn A., 2012, Pembuatan Salep Anti Jerawat dari Ekstrak Rimpang Temulawak (Curcuma xanthorrhiza Roxb.), Jurnal Ilmiah Farmasi, 3(2), 45-49 
